\title{
Pengaruh Iringan Gitar Terhadap Kecerdasan \\ Emosional Anak di PAUD Terpadu Bhakti Bunda Padang
}

\author{
Muthia Arya Putri ${ }^{1}$, Indra Yeni ${ }^{2}$, Rakimahwati ${ }^{3}$ \\ Program Studi PG-PAUD Fakultas IImu Pendidikan \\ Universitas Negeri Padang \\ Email : muthiaaryap@gmail.com
}

\begin{abstract}
Abstrak
Penelitian ini bertujuan untuk mengetahui sejauh mana pengaruh iringan gitar terhadap kecerdasan emosional. Penelitian menggunakan pendekatan kuantitatif yang berbentuk quasy experiment. Berdasarkan analisis data, diperoleh rata-rata hasil tes kelas eksperimen adalah 88,2 sedangkan pada kelas kontrol 77,8 . Berdasarkan perhitungan $t$-test diperoleh $t_{\text {hitung }}$ lebih besar dari $t_{\text {tabel }}$ menunjukkan bahwa terdapat perbedaan yang signifikan antara kedua kelas tersebut. Dengan demikian dapat disimpulkan bahwa terdapat pengaruh yang signifikan antara iringan gitar terhadap kecerdasan emosional anak di PAUD Terpadu Bhakti Bunda Padang
\end{abstract}

\section{Kata Kunci : Iringan Gitar; Kecerdasan Emosional \\ PENDAHULUAN}

Anak usia dini adalah anak yang berada di rentangan usia 0-8 tahun, dimana pada usia ini semua aspek perkembangan tumbuh, berkembang, matang dan sempurna secara bertahap dan berkesinambungan yang menentukan tahap perkembangan anak selanjutnya. Pendidikan anak usia dini pada hakikatnya ialah pendidikan yang diselenggarakan dengan tujuan untuk memfasilitasi pertumbuhan dan perkembangan anak secara menyeluruh dan mengembangkan potensi secara maksimal. Menurut Departemen Pendidikan Nasional Indonesia, Pendidikan Anak Usia Dini (PAUD) adalah suatu upaya pembinaan yang ditujukan bagi anak sejak lahir sampai dengan usia enam tahun, yang dilakukan dengan memberi rangsangan pendidikan untuk membantu dan perkembangan jasmani dan rohani agar anak memiliki kesiapan dalam memasuki pendidikan lanjut. Saat ini pendidikan prasekolah di Indonesia dilaksanakan melalui jalur formal, yaitu Taman Kanak-Kanak dan kelompok PAUD nonformal yang diselenggarakan secara mandiri oleh masyarakat serta berbagai organisasi keagamaan.

Pengembangan yang dilaksanakan di PAUD meliputi pengembangan kemampuan dasar dan pengembangan pembiasaan. 
Pada pengembangan kemampuan dasar aspek yang dikembangkan meliputi berbahasa, kognitif, fisik atau motorik, sedangkan pada pengembangan pembiasaan aspeknya meliputi perkembangan moral dan nilai-nilai agama serta pengembangan sosial, emosional, dan kemandirian.

Salah satu bidang kemampuan pembiasaan yang dikembangkan dalam pendidikan anak usia dini adalah kecerdasan emosional. Menurut Mashar (2011:60) Kecerdasan emosional adalah kemampuan untuk mengenali, mengolah dan mengontrol emosi agar anak mampu merespons secara positif setiap kondisi yang merangsang munculnya emosi. Dengan kecerdasan emosional tersebut seorang dapat menempatkan emosinya pada porsi yang tepat, memilah kepuasan dan mengatur suasana hati.

Kecerdasan emosional perlu diasah sejak dini, karena kecerdasan emosional merupakan salah satu poros keberhasilan individu dalam berbagai aspek kehidupan. Kemampuan anak mengembangkan kecerdasan emosinya, berkorelasi positif dengan keberhasilan akademis, sosial dan kesehatan mentalnya. Anak yang memiliki kecerdasan emosi tinggi identik dengan anak yang bahagia, bermotivasi tinggi dan mampu bertahan dalam menjalani berbagai kondisi stress yang dihadapi.

Kecerdasan emosional anak dapat diasah melalui kegiatan kegiatan pembiasaan yang diorganisasikan berdasarkan kebutuhan, minat dan karakterisitik anak. Pengembangan kecerdasan emosi dilakukan melaui kegiatan yang menyenangkan dan menggembirakan bagi anak yaitu bernyayi. Namun, bernyanyi bisa menjadi kegiatan yang membosankan bagi anak karena media bernyanyi digunakan yang kurang menarik, sehingga anak tidak bersemangat mengikuti kegiatan bernyanyi.

Willis (2012:65) mengemukakan salah satu cara mengembangkan emosi anak adalah dengan latihan musik. Latihan musik ini adalah untuk memperhalus perasaan, sehingga perasaan-perasaan negative akan hilang karena anak berusaha menumpahkan emosinya pada musik. Musik merupakan sesuatu yang nyata dan senantiasa hadir dalam kehidupan manusia. Menurut AT. Mahmud dalam Rachmawati (2011:63), menyatakan bahwa musik adalah aktivitas kreatif. Seorang anak yang kreatif, antara lain tampak pada rasa ingin tahu, sikap ingin mencoba, dan daya imajinasi yang berkembang dan melahirkan suasana khas terhadap penyajian musik atau nyanyian.

Musik merupakan media ekspresi dan rekreasi yang dibutuhkan anak, Chazan dalam Mutiah (2010:170) menyatakan bahwa musik memberikan kesempatan kepada anak untuk melepaskan emosinya yang tertahan maupun mengeluarkan emosi yang tidak dapat diterima oleh lingkungan. 
Apresiasi musik di taman kanak kanak erat kaitannya dengan nyanyian, alat musik, dan gerak jasmaniah. Apresiasi musik di taman kanak kanak erat kaitannya dengan nyanyian, alat musik, dan gerak jasmaniah. Jannah (2003: 63), menyatakan dengan adanya nyanyian tersebut dalam proses pembelajaran, maka pendidik dapat mengiringinya dengan instrument/ music. Harbert dalam Mutiah (2010: 170), menyatakan bahwa musik mempunyai efek untuk penyaluran perasaan. Musik dapat memberikan perasaan kepuasan dan perasaan nyaman serta dapat bersifat sebagai terapi. Djohan (2009: 87), juga menyatakan bahwa musik dapat menjadi sarana pengekspresian diri. Musik diakui mempunyai kekuatan untuk mengatur dan menggugah emosi.

David Ewen dalam Hastomi (2012: 16) menyatakan bahwa musik meliputi melodi dan harmoni sebagai ekspresi dari segala sesuatu yang ingin diungkapkan, terutama aspek emosional. Sehingga melalui musik guru dapat mengembangkan kecerdasan emosional anak. Agar memperoleh hasil maksimal, maka musik pengiring harus memiliki harmonisasi yang kuat salah satunya adalah melalui iringan alat musik gitar.

Hakim (2004: 9), mengemukakan gitar adalah suatu jenis alat musik harmonis. Artinya, alat musik ini bisa digunakan untuk membentuk chord guna mengiringi lagu. Sejalan dengan itu, Sheppard (2007: 358), juga mengemukakan gitar adalah instrumen yang baik untuk anak-anak. Bernyanyi diiringi dengan alat musik gitar menjadi menyenangkan dan merangsang serta memotivasi anak untuk bernyanyi dengan lebih percaya diri.

Penggunaan alat musik gitar menjadikan anak terlatih membedakan not-not sederhana, anak dapat bernyanyi sesuai dengan tempo lagu, serta bernyanyi dengan iringan gitar juga memberikan kesempatan pada anak untuk melepaskan emosi yang sesuai dengan suasana lagu, anak menjadi lebih percaya diri, bersemangat dan tidak mudah bosan. Anak dapat merespons terhadap ritme dengan berbagai cara bertepuk tangan, melompat, berputar, dan lain-lain.

Hakim (2004: 9), mengemukakan gitar adalah suatu jenis alat musik harmonis. Artinya, alat musik ini bisa digunakan untuk membentuk chord guna mengiringi lagu. Sejalan dengan itu, Sheppard (2007: 358), juga mengemukakan gitar adalah instrumen yang baik untuk anak-anak. Bernyanyi diiringi dengan alat musik gitar menjadi menyenangkan dan merangsang serta memotivasi anak untuk bernyanyi dengan lebih percaya diri.

Penggunaan alat musik gitar menjadikan anak terlatih membedakan not-not sederhana, anak juga akan lebih mudah dan cepat dalam memahami nada yang ada pada lagu baik lagu yang sudah pernah 
ia dengar maupun lagu yang belum pernah ia dengar, anak dapat bernyanyi sesuai dengan tempo lagu, serta bernyanyi dengan iringan gitar juga memberikan kesempatan pada anak untuk melepaskan emosi yang sesuai dengan suasana lagu, anak menjadi lebih percaya diri, bersemangat dan tidak mudah bosan. Anak dapat merespons terhadap ritme dengan berbagai cara bertepuk tangan, melompat, berputar, dll.

\section{METODE PENELITIAN}

Berdasarkan permasalahan yang diteliti maka bentuk penelitian ini adalah kuantitatif dengan jenis quasy eksperiment (eksperimen semu). Populasi dalam penelitian ini adalah murid PAUD Terpadu Bhakti Bunda Padang yang beralamat di Jalan Bhakti No.504 Kecamatan Koto Tangah, Kota Padang.

Sampel pada penelitian ini menggunakan teknik cluster sampling dimana teknik ini berdasarkan pada pertimbangan apabila obyek yang akan diteliti atau sumber data sangat luas. Namun, mengenai penetapan besar kecilnya sampel tidaklah ada satu ketetapan mutlak, artinya tidak ada suatu ketetapan berpa persen sample harus diambil. Berdasarkan cara di atas, maka kelas yang akan dijadikan dalam penelitian ini adalah kelompok B1 dan B2 yang masing-masing kelas berjumlah 10 orang anak.

Instrumen ini menggunakan skala likert untuk penilaiannya. Menurut Sugiyono (2010: 135) Sangat Baik diberi skor 5 (SB), Baik diberi skor 4 (B), Cukup Baik diberi skor 3 (CB), Tidak Baik diberi skor 2 (TB), Sangat Tidak Baik diberi skor 1 (STB).

Menurut Arikunto (2012:211) validitas adalah suatu ukuran yang menunjukkan tingkat-tingkat kevalidan atau kesahihan sesuatu instrumen. Suatu instrumen yang valid atau sahih mempunyai validitas tinggi. Sebaliknya, instrumen yang kurang valid berarti memiliki validitas rendah.

Reliabilitas Instrumen, menurut Arikunto (2012: 221) reliabilitas menunjuk pada satu pengertian bahwa sesuatu instrumen cukup dapat dipercaya untuk digunakan sebagai alat pengumpul data karena instrumen tersebut sudah baik. Pengujian reabilitas instrumen dilakukan dengan rumus Alpha.

Teknik analisis data yang digunakan dalam penelitian adalah membandingkan perbedaan dari dua rata-rata nilai, sehingga dilakukan dengan uji $\mathrm{t}(\mathrm{t}$-test). Sebelum melakukan uji $\mathrm{t}(\mathrm{t}$-test), terlebih dahulu peneliti akan melakukan uji normalitas dan uji homogenitas.

Uji normalitas bertujuan untuk melihat apakah sampel berdistribusi normal atau tidak. Untuk menguji normalitas data antara lain dengan Kertas Peluang dan Chi Kuadrat. Uji homogenitas sangat diperlukan sebelum membandingkan dua kelompok atau lebih, agar perbedaan yang 
ada bukan disebabkan oleh adanya perbedaan data dasar (ketidak homogenan kelompok yang dibandingkan).

Jika sudah diketahui sebuah data berdistribusi normal dan bersifat homogen baru dilakukan analisis data sesuai dengan teknik analisis yang telah ditentukan, yaitu dengan mencari perbandingan dengan menggunakan t-test. Menguji data yang telah diperoleh tersebut dengan rumus t-test Syafril (2010: 176).

\section{HASIL}

Untuk dapat menarik kesimpulan dari hasil penelitian, dilakukan uji hipotesis dengan menggunakan uji t. Sebelum melakukan uji t terlebih dahulu dilakukan uji normalitas dan uji homogenitas terhadap hasil penelitian.

Data hasil pre-test kecerdasan emosional anak dikelompok eksperimen dan kelompok kontrol diolah untuk menentukan uji normalitas. Pada uji normalitas ini digunakan uji Liliefors seperti yang dikemukakan pada teknik analisis data. Analisis normalitas pada kelompok eksperimen dan kelompok kontrol.

Berdasarkan uji normalitas kelompok eksperimen dan kelompok kontrol diperoleh harga $L_{o}$ dan $L_{t}$ pada taraf nyata 0,05 untuk $N$ $=10$ seperti tabel berikut :

Tabel 1

Hasil Perhitungan Pengujian Liliefors Pre-test Kelompok Eksperimen dan Kelompok Kontrol

\begin{tabular}{|c|l|c|c|c|c|c|}
\hline No & Kelompok & $\mathbf{N}$ & A & L0 & Lt & Keterangan \\
\hline 1 & Eksperimen & 10 & 0,05 & 0,117 & 0,258 & Normal \\
\hline 2 & Kontrol & 10 & 0,05 & 0,204 & 0,258 & Normal \\
\hline
\end{tabular}

Berdasarkan tabel 1 terlihat bahwa kelompok eksperimen nilai $L_{\text {hitung }} \mathbf{0 , 1 1 7}$ lebih kecil dari $L_{\text {tabel }} \mathbf{0 , 2 5 8}$ untuk a 0,05. Dengan demikian nilai kelompok eksperimen berasal dari data yang berdistribusi normal. Untuk kelompok kontrol diperoleh $L_{\text {hitung }} \mathbf{0 , 2 0 4}$ lebih kecil dari $L_{\text {tabel }} \mathbf{0 , 2 5 8}$ untuk $\alpha$ 0,05 . Ini berarti bahwa data kelompok kontrol berasal dari data yang berdistribusi normal.

Pengujian persyaratan yang kedua adalah pengujian homogenitas dengan menggunakan uji Barlett. Pengujian ini bertujuan untuk mengetahui apakah data berasal dari kelompok yang homogen, antara kelompok eksperimen dan kelompok kontrol. Jika chi kuadrat hitung < chi kuadrat tabel berarti data berasal dari kelompok yang homogen.

Hal ini sesuai dengan apa yang dikemukakan oleh Syafril (2010:208) bahwa :"Jika hasil perhitungan dari $X^{2}$ hitung lebih kecil dari $X^{2}$ tabel 
berarti bahwa data berasal dari kelompok yang homogen, sebaliknya jika $X^{2}$ hitung lebih besar daripada $X_{\text {tabel }}^{2}$ maka kelompok tersebut tidak homogen ".

Hasil perhitungan diperoleh $X^{2}$ hitung sebesar 0,322 seperti yang di tuliskan dalam tabel berikut :

Tabel 2

Hasil Perhitungan Uji Homogenitas Pre-test

Kelas Eksperimen dan Kelas Kontrol

\begin{tabular}{|c|c|c|c|c|}
\hline Kelas & $\mathrm{A}$ & $\mathrm{X}_{\text {hitung }}^{2}$ & $\mathrm{X}_{\text {tabel }}^{2}$ & kesimpulan \\
\hline Eksperimen & 0,05 & 0,322 & 3,841 & Homogen \\
\hline kontrol & & & & \\
\hline
\end{tabular}

Dari Tabel 2 tampak bahwa $X^{2}$ hitung kelompok eksperimen dan kelompok kontrol lebih kecil dari $X_{\text {tabel }}^{2}\left(X^{2}{ }_{\text {hitung }}<X^{2}{ }_{\text {tabel }}\right)$, berarti kelompok eksperimen dan kelompok kontrol memiliki varians yang homogen.

Setelah dilakukan uji normalitas dan uji homogenitas, diketahui bahwa kedua kelas sampel berdistribusi normal dan mempunyai varians homogen. Maka dapat dilanjutkan dengan pengujian hipotesis dengan menggunakan teknik t-tes.

Jika $\boldsymbol{t}_{\text {hitung }}>\boldsymbol{t}_{\text {tabel }}$ maka $\mathrm{H}_{0}$ ditolak dan $\mathrm{H}_{\mathrm{a}}$ diterima

Jika $\boldsymbol{t}_{\text {hitung }}<\boldsymbol{t}_{\text {tabelmaka }} \mathrm{H}_{0}$ diterima dan $\mathrm{H}_{\mathrm{a}}$ ditolak

Berikut ini akan digambarkan pengolahan data dengan t-test:

Tabel 3

Hasil Perhitungan Nilai Pre-test

Kelompok Eksperimen dan Kelompok Kontrol

\begin{tabular}{|c|c|c|}
\hline Aspek & $\begin{array}{c}\text { Kelomok } \\
\text { Eksperimen }\end{array}$ & $\begin{array}{c}\text { Kelompok } \\
\text { Kontrol }\end{array}$ \\
\hline $\mathrm{N}$ & 10 & 10 \\
\hline $\mathrm{X}_{\text {rata-rata }}$ & 74,7 & 73,1 \\
\hline
\end{tabular}

T tabel untuk taraf nyata $\alpha=0,05(5 \%)$ dengan df sebesar 18 adalah $=2,10092$ Dengan demikian, dapat diketahui bahwa pada taraf nyata

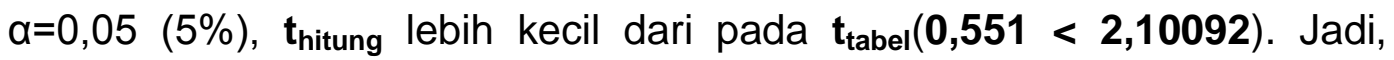
dapat disimpulkan bahwa tidak terdapat perbedaan yang signifikan antara kecerdasan emosional anak di kelas eksperimen dan kelas kontrol dalam nilai pretest. 


\section{Tabel 4}

Hasil Perhitungan Pre-test Pengujian Dengan t-test

\begin{tabular}{|c|c|c|c|c|c|c|}
\hline \multirow{2}{*}{ No } & Kelompok & \multirow{N}{*}{$\mathrm{N}$} & \multicolumn{2}{|c|}{ Hasil } & & Rata- \\
\cline { 4 - 5 } & & thitung & $\mathbf{\alpha} \mathbf{0 , 0 5}$ & keputusan \\
\hline 1 & Eksperimen & 10 & 74,7 & \multirow{2}{*}{0,551} & 2,10092 & Terima \\
\hline 2 & kontrol & 10 & 73,1 & & \\
\hline
\end{tabular}

T tabel untuk taraf nyata $\alpha=0,05(5 \%)$ dengan df sebesar 18 adalah $=2,10092$ Dengan demikian, dapat diketahui bahwa pada taraf nyata

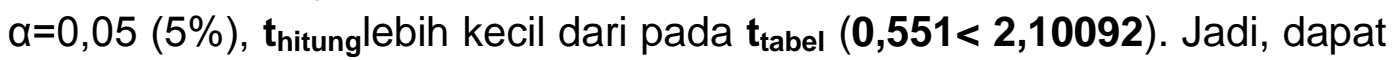
disimpulkan bahwa tidak terdapat perbedaan yang signifikan antara hasil pre-test (kemampuan awal) kecerdasan emosional di kelompok eksperimen dengan kelompok kontrol di PAUD Terpadu Bhakti Bunda Padang.

Data post test penelitian kelompok eksperimen dan kelompok kontrol diolah untuk menentukan uji normalitas. Pada uji normalitas ini digunakan uji Liliefors seperti yang dikemukakan pada teknik analisis data. Analisis normalitas pada kelompok eksperimen dan kelompok.

Berdasarkan uji normalitas kelompok eksperimen dan kelompok kontrol diperoleh harga $L_{0}$ dan $L_{t}$ pada taraf nyata 0,05 untuk $N=10$ seperti pada tabel berikut:

Tabel 5

Hasil Perhitungan Pengujian Liliefors Post-test Kelompok Eksperimen dan Kelompok Kontrol

\begin{tabular}{|c|c|c|c|c|c|c|}
\hline No & Kelompok & $\mathrm{N}$ & $\mathrm{A}$ & $\mathrm{L}_{\mathbf{0}}$ & $\mathrm{L}_{\mathbf{t}}$ & Keterangan \\
\cline { 1 - 1 } 1 & Eksperimen & \multirow{2}{*}{10} & \multirow{2}{*}{0,05} & 0,153 & \multirow{2}{*}{0,258} & normal \\
\cline { 1 - 1 } 2 & Kontrol & & & 0,173 & & \\
\hline
\end{tabular}

Berdasarkan tabel 16 terlihat bahwa kelompok eksperimen nilai $L$ hitung 0,153 lebih kecil dari $L$ tabel 0,258 untuk a 0,05. Dengan demikian nilai kelompok eksperimen berasal dari data yang berdistribusi normal. Untuk kelompok kontrol diperoleh $L$ hitung $\mathbf{0 , 1 7 3}$ lebih kecil dari $L$ tabel $\mathbf{0 , 2 5 8}$ untuk a 0,05. Ini berarti bahwa data kelompok kontrol berasal dari data yang berdistribusi normal.

Berdasarkan tabel 16 terlihat bahwa kelompok eksperimen nilai $L$ hitung 0,153 lebih kecil dari $L$ tabel 0,258 untuk a 0,05. Dengan demikian nilai kelompok eksperimen berasal dari data yang berdistribusi normal. Untuk kelompok kontrol diperoleh $L$ hitung $\mathbf{0 , 1 7 3}$ lebih kecil dari $L$ tabel $\mathbf{0 , 2 5 8}$ untuk a 0,05. Ini berarti bahwa data kelompok kontrol berasal dari data yang berdistribusi normal. 


\section{Tabel 6}

Hasil Uji Homogenitas Post-test

Kelompok Eksperimen dan Kelompok Kontrol

\begin{tabular}{|c|c|c|c|c|}
\hline Kelompok & $\mathrm{A}$ & $\mathrm{X}^{2}{ }_{\text {hitung }}$ & $\mathrm{X}^{2}{ }_{\text {tabel }}$ & Kesimpulan \\
\cline { 1 - 4 } Eksperimen & \multirow{2}{*}{0,05} & 0,782 & 3,841 & Homogen \\
\hline
\end{tabular}

Dari Tabel 6 tampak bahwa $X^{2}$ hitung kelompok eksperimen dan kelompok kontrol lebih kecil dari $\mathrm{X}^{2}{ }_{\text {tabel }}\left(\mathrm{X}^{2}\right.$ hitung $<\mathrm{X}^{2}$ tabel), berarti kelompok eksperimen dan kelompok kontrol memiliki varians yang homogen.

Setelah dilakukan uji normalitas dan uji homogenitas, diketahui bahwa kedua kelompok sampel berdistribusi normal dan mempunyai varians homogen. Maka dapat dilanjutkan dengan pengujian hipotesis dengan menggunakan teknik t-test.

Jika $\boldsymbol{t}_{\text {hitung }}>\boldsymbol{t}_{\text {tabel }}$ maka $\mathrm{H}_{0}$ ditolak dan $\mathrm{H}_{\mathrm{a}}$ diterima

Jika $\boldsymbol{t}_{\text {hitung }}<\boldsymbol{t}_{\text {tabelmaka }} \mathrm{H}_{0}$ diterima dan $\mathrm{H}_{\mathrm{a}}$ ditolak

Berikut ini akan digambarkan pengolahan data dengan t-test:

Tabel 7

Hasil Perhitungan Nilai Post-test

Kelompok Eksperimen dan Kelompok Kontrol

\begin{tabular}{|c|c|c|}
\hline Aspek & $\begin{array}{c}\text { Kelompok } \\
\text { eksperimen }\end{array}$ & $\begin{array}{c}\text { Kelompok } \\
\text { kontrol }\end{array}$ \\
\hline $\mathrm{N}$ & 10 & 10 \\
\hline $\mathrm{X}_{\text {rata-rata }}$ & 88,2 & 77,2 \\
\hline & 58,2 & 40,2 \\
\hline
\end{tabular}

T tabel untuk taraf nyata $\alpha=0,05(5 \%)$ dengan df sebesar 26 adalah $=2,10092$ Dengan demikian, dapat diketahui bahwa pada taraf nyata $\alpha=0,05(5 \%)$, $\mathbf{t}_{\text {hitung }}$ lebih besar dari pada $\mathbf{t}_{\text {tabel }}(3,151>2,056)$. Jadi, dapat disimpulkan bahwa $\mathrm{H}_{\mathrm{a}}$ diterima yaitu: iringan gitar berpengaruh terhadap kecerdasan emosional anak di PAUD Terpadu Bhakti Bunda Padang.

Setelah dilakukan perhitungan nilai pre-test dan post-test kelompok eksperimen dan kontrol maka selanjutnya akan dilakukan perbandingan antara nilai pre-test dan nilai post-test, yang tujuannya untuk melihat apakah ada perbedaan nilai post-test dan nilai pre-test anak.

Perbandingan hasil perhitungan nilai pre-test dan nilai post-test. Pada pre-test nilai tertinggi yang diperoleh anak kelas eksperimen yaitu 83 dan nilai terendah 63, dengan rata-rata 74,7 sedangkan pada kelas kontrol nilai tertinggi yang diperoleh anak yaitu 86 dan nilai terendah 63 dengan rata-rata 73,1 . Pada post-test nilai tertinggi yang diperoleh anak kelas eksperimen yaitu 96 dan nilai terendah 73 dengan rata-rata 88,2 
sedangkan pada kelas kontrol post-test nilai tertinggi yang diperoleh anak yaitu 90 dan nilai terendah 70 dengan rata-rata 77,8 .

\section{PEMBAHASAN}

Kecerdasan emosional adalah kemampuan merasakan, memahami, dan secara selektif menerapkan daya dan kepekaan emosi sebagai sumber energy dan pengaruh yang manusia. Mashar (2011: 60), menyatakan kecerdasan emosional adalah kemampuan untuk mengenali, mengolah dan mengontrol emosi agar anak mampu merespons secara positif setiap kondisi yang merangsang munculnya emosi.

Seorang guru harus mampu mengembangkan kecerdasan emosional anak karena akan banyak manfaat yang akan diperoleh anak. Sehingga diperlukan suatu upaya dalam mengembangkan kecerdasan emosional anak yaitu, dengan menghadirkan media yang menarik, dan menyenangkan, salah satunya adalah menggunakan iringan alat musik gitar.

Menurut Asriadi (2005: 1), Gitar adalah alat musik petik berdawai senar dan berpapan nada. Gitar dapat menghasilkan melodi dan akor dalam jumlah dan variasi yang lebih banyak dibandingkan dengan alat musik lain. Dengan alat musik gitar, bisa bermusik kapanpun dan dimanapun serta lebih praktis karena mudah dibawa kemana-mana.

Hakim (2004: 9), mengemukakan gitar adalah suatu jenis alat musik harmonis. Artinya, alat musik ini bisa digunakan untuk membentuk chord guna mengiringi lagu. Sheppard (2007: 358), mengemukakan gitar adalah instrumen yang baik untuk anak-anak. Bernyanyi diiringi dengan alat musik gitar menjadi menyenangkan dan merangsang serta memotivasi anak untuk bernyanyi dengan lebih percaya diri.

Media ini juga dapat membantu anak bernyanyi sesuai dengan irama dan tempo, alat musik ini juga menghasilkan nada-nada secara harmoni sebagai pengiring atau penyelaras nyanyian dan media ini memiliki bunyi yang khas sehingga membuat anak lebih bersemangat dan tertarik dalam mengikuti kegiatan bernyanyi. Bernyanyi dengan iringan gitar juga memberikan kesempatan pada anak untuk melepaskan emosi yang sesuai dengan suasana lagu, anak menjadi lebih percaya diri, bersemangat dan tidak mudah bosan.

Anak dengan kecerdasan emosional yang menonjol mampu dengan percaya diri mengikuti kegiatan bernyanyi, mampu menyeleraskan emosi sesuai dengan irama dan suasana lagu, dan mampu mengontrol emosi. Anak dapat merespons terhadap ritme dengan berbagai cara bertepuk tangan, melompat, berputar, dll. 
Pada kegiatan bernyanyi, guru merancang kegiatan pembelajaran sesuai tema dan sub tema, dan menggunakan iringan gitar pada setiap nyanyian sesuai subtema. Kegiatan bernyanyi ini membuat anak tidak merasa bosan, monoton, dan sulit dalam pembelajaran. Kelas yang menggunakan iringan tamburin terkesan monoton dan kurang memberikan ketertarikan bagi anak. Pada kelas tersebut anak lebih banyak diam, dan kurang percaya diri serta ada yang menganggu teman, bernyanyi dengan berteriak, dan menyanyikan lagu bahagia dengan tidak bersemangat. Hasil kecerdasan emosional anak kelas eksperimen yang diberikan perlakuan menggunakan iringan gitar lebih baik dari pada hasil kecerdasan emosional anak dikelas kontrol yang menggunakan iringan tamburin, dapat dilihat dari rata-rata anak kelas eksperimen yang lebih tinggi dari pada kelas kontrol.

Maka dapat disimpulkan bahwa penggunaan iringan gitar berpengaruh terhadap kecerdasan emosional anak, dan memberikan kesan menyenangkan dan semangat bagi anak dalam kegiatan bernyanyi. Selain itu anak tidak mudah bosan dalam kegiatan pembelajaran karena diberikan kesempatan untuk bernyanyi, tujuannya agar anak tidak merasa dipaksa dalam mengikuti kegiatan pembelajaran.

\section{SIMPULAN}

Hasil penelitian yang diperoleh bahwa terdapat perbedaan nilai rata-rata hasil kecerdasan emosional kelas eksperimen (B2) dengan kelas kontrol (B1) di PAUD Terpadu Bhakti Bunda Padang. Hal ini membuktikan bahwa dengan menggunakan iringan gitar berpengaruh terhadap kecerdasan emosional anak. Sehingga nilai rata-rata yang diperoleh dari kelas eksperimen lebih tinggi $(88,2)$ dibandingkan kelas kontrol $(77,8)$.

Dari hasil uji hipotesis didapat $t_{\text {hitung }}>t_{\text {tabel }}$ dimana $3,151>2,10092$ yang dibuktikan dengan taraf signifikan a 0,05 ini berarti terdapat perbedaan yang signifikan antara kecerdasan emosional kelompok eksperimen dan kelompok kontrol di PAUD Terpadu Bhakti Bunda Padang.

Iringan gitar memberikan hasil yang signifikan terhadap kecerdaan emosional, hal ini disebabkan karena beberapa faktor yakni kegiatan pembelajaran yang menyenangkan dan lebih bersemangat, anak merasa lebih percaya diri dan mampu mengontrol emosi serta mengekspresikan perasaan sesuai irama dan suasana lagu.

Berdasarkan kesimpulan hasil penelitian yang telah dipaparkan di atas, maka peneliti ingin mengemukakan beberapa saran, yaitu; iringan gitar diharapkan dapat dipergunakan sebagai salah satu alternatif metode pembelajaran dalam mengembangkan kecerdasan emosional anak usia dini bagi pendidik anak usia dini, karena iringan gitar terbukti berpengaruh 
dalam mengembangkan kecerdasan emosional anak sehingga dapat meningkatkan kualitas pembelajaran dan suasana yang menyenangkan dan tidak membosankan bagi anak dalam setiap pembelajaran. Selain itu, kepada peneliti yang ingin melanjutkan penelitian ini diharapkan dapat menjadi sumber bacaan/literature bagi peneliti lain untuk mengembangkan penelitian yang lama.

\section{DAFTAR PUSTAKA}

Arikunto,Suharsimi. 2012. Dasar-Dasar Evaluasi. Jakarta:Rineka Cipta Asriadi, Derry. 2005. Panduan Mengiri Lagu dengan Gitar. Jakarta: Kawan Pustaka

Hakim, Thursan. 2004. Teknik Paling Praktis Belajar memainkan Biola dan Gitar. Tanggerang: PT Kawan Pustaka

Hastomi, Sumaryati. 2012. Terapi Musik. Jogjakarta: PT Buku

Kita Jannah, Lili Alfiyatul. 2013. Kesalahan-kesalahan guru paud yang sering

dianggap sepele. Jogkajarta: DIVA Press

Mashar, Riana. 2011. Emosi Anak Usia Dini Dan Strategi

Pengembangannya. Jakarta: Kencana

Mutiah, Diana. 2010. Psikologi Bermain Anak Usia Dini. Jakarta:kencana

Rachmawati, Yeni.

Euis Kurniati. 2011. Strategi pengembangan kreativitas pada anak usia taman

Kanak-kanak. Jakarta: kencana

Sheppard, Philip. 2007. Music makes your child smarter. Jakarta: PT

Gramedia Pustaka Utama

Sugiyono. 2011. Metode Penelitian Pendidikan. Bandung : CV Alfabeta Tridhonanto, Al. 2010. Meraih Sukses Dengan Kecerdasan Emosional.

Jakarta: Elex Media Komputindo

Willis, Sofyan S. 2012. Psikologi Pendidikan. Bandung: Alfabet 